UDC 726(497.11)"1815/1839"

https://doi.org/10.18485/ms_zmslu.2021.49.6

Оригинални научни рад

Ана Д. Костић

\title{
САКРАЛНО ГРАДИТЕЉСТВО И ГРАДИТЕЉИ ЦРКАВА У КНЕЖЕВИНИ СРБИЈИ У ВРЕМЕ ПРВЕ ВЛАДАВИНЕ КНЕЗА МИЛОША ОБРЕНОВИЋА (1815-1839)
}

\begin{abstract}
САЖЕТАК: У време прве владавине кнеза Милоша Обреновића (1815-1839), у Кнежевини Србији је подигнут и обновљен велики број цркава. Активности везане за подизање и обнављање храмова биле су део кнежеве државотворне и личне политике, те су разгранавање парохијске мреже и обезбеђивање градитеља за тај подухват били један од императива. Иако на досадашњем ступњу истражености сакралног градитељства овог периода за велики број храмова није могуће утврдити ко су били градитељи, захваљујући сачуваној, и у великој мери публикованој, архивској грађи о многим градитељима постоје сачувани подаци, иако некад непотпуни. Намера је да се овим радом употпуне досадашња знања о сакралном градитељству и градитељима цркава у Србији од 1815. до 1839. године, идентификовањем одређених историјских оквира који су омогућили појаву и доминацију појединих градитељских струја, са акцентом на најзначајнија градитељска имена и њихове појединачне опусе.
\end{abstract}

КљУЧНЕ РЕЧИ: Кнежевина Србија, прва владавина кнеза Милоша Обреновића, сакрално градитељство, балкански градитељи.

Период Првог и Другог српског устанка против османске власти (1804-1815) донео је талас великих разарања којим су били захваћени манастири и цркве, међу којима су били и они малобројни храмови изграђени и обновљени у кратком времену мира, између устанака (КолАРић 1959: 8-10; Класицизам 1967: 23; Вујовић 1986: 50, 75-84, 92-94, 97-98, 101). Одмах након Другог српског устанка, 1815. године, испрва скромно и уз незнатна средства, почињу да се обнављају и подижу мањи храмови, попут оних у селу Цветановцима (1815), Врелу (1816), Раброву (1817), Тополи (1815), и обнављају манастири међу којима су Боговађа (1816) и Никоље (1817), те испосница Светог Саве код Студенице (1815) (КолАРић 1959: 10; ПАвловић 1962: 30; Класицизам 1967: 24; ВујОвић 1986: 101-102; НЕСтОРОвИЋ 2006: 119). Након 1817. године, када Милош

\footnotetext{
* Универзитет у Београду, Филозофски факултет, anchikostic@gmail.com
} 


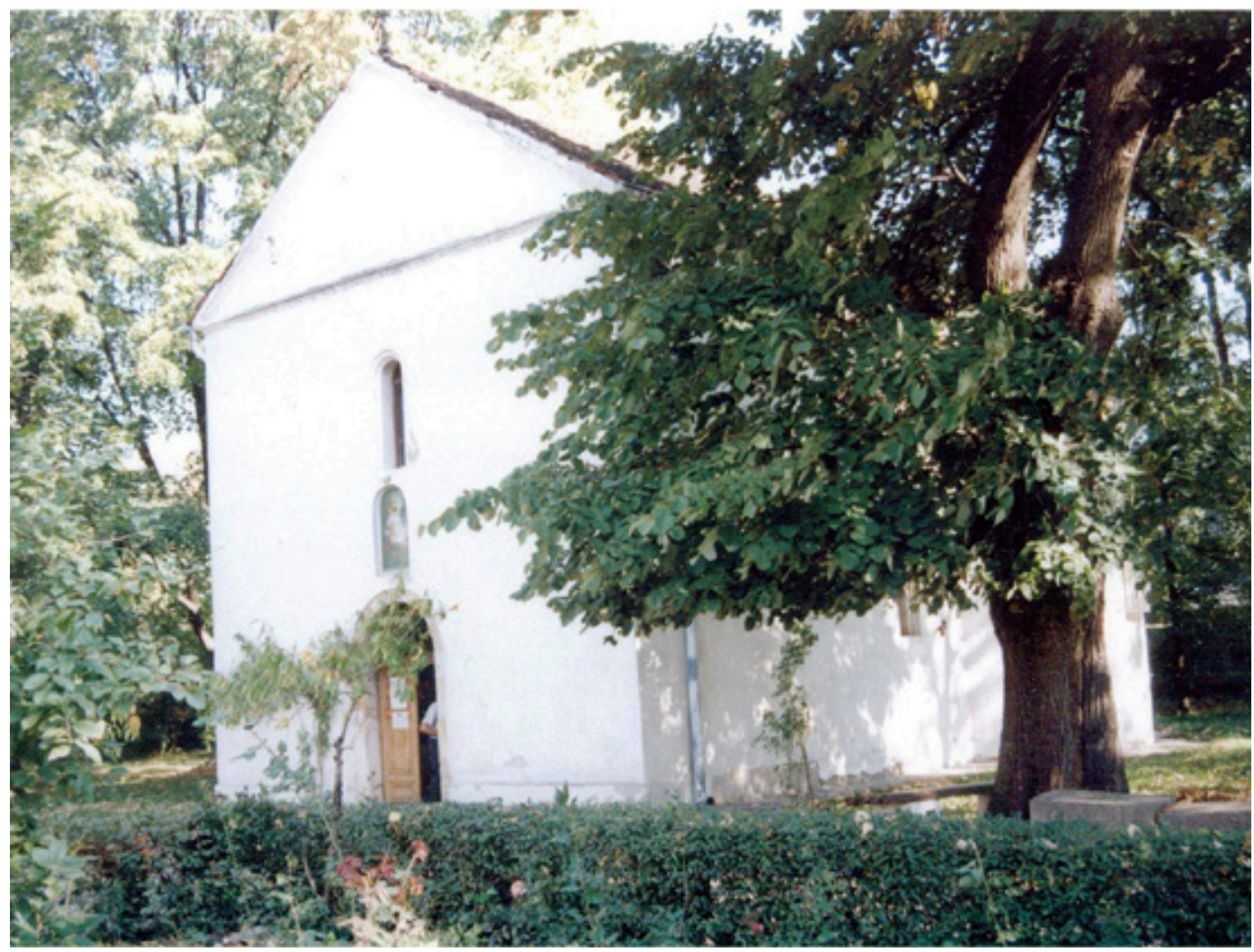

Сл. 1. Стара црква у Јагодини, Милутин Гођевац, 1818.

Обреновић добија титулу кнеза, паралелно са његовим дипломатским напорима и преговорима са Османским царством везаним за добијање политичке и црквене аутономије, те јачањем личног положаја и повећањем прихода, долази до осетнијег напретка у изградњи црквених грађевина (Вујовић 1986: 61; Љушић 2004: 1-21, 114-117). Године 1818. кнез гради цркву у Јагодини (сл. 1) и придворну цркву у Крагујевцу, а наредне године и цркву у Пожаревцу, а у време између 1820. и 1830. његовим трошком, личним прилозима, као и залагањем локалног становништва, свештенства, устаничке елите и народних старешина подигнут је знатан број храмова (МАРковит 1942: 121-130; КОЛАРИЋ 1959: 11-13; КАшИЋ 1960: 267-271; СТРАњАКОВИЋ 1960: 262-267; Класицизам 1966: 24-25; Вујовић 1973: X-XI; 1986: 61). Највећи замајац у подизању и опремању православних храмова уследио је након доношења Хатишерифа 1830. године. Овај правни акт био је од великог значаја за државност Србије јер је њиме она постала наследна монархија под султановим сизеренством, са самоуправним правом и слободом вероисповести, што је подразумевало слободно подизање и обнављање 
цркава и манастира (Љушић 2004: 4-14). Као последица Хатишерифа из 1830. Србији је издат Конкордат 1831, којим је она добила право на унутрашњу црквену аутономију (Слијепчевић 1991, 312-318; Љушић 2004, 21-23). Ови правно-политички оквири, праћени побољшаним економским условима, омогућили су динамично разгранавање парохијске мреже (Вујовић 1986: 61, 102-103). Поред реалних потреба, активности везане за обнављање и подизање великог броја храмова у време које је обележило прву владавину кнеза Милоша Обреновића (1815-1839) (ЂорЂЕвић 1983: 147-152; Вујовић 1986: 108), биле су део кнежеве државне политике и владарске идеологије иза којих је стајала свест о значају Цркве као институције у конституисању српске националне државе (Костић 2016: 18-22; Ђокић 2018: 122-127; Пузовић 2018: 81-89). Такође, велика кнежева ктиторска и приложничка делатност у овом периоду произлазила је и из идеолошких конотација његовог представљања као ослободиоца и доброчинитеља. Тиме су исказивани његов хришћански идентитет, али и моћ и величајност као владара (МАКУљЕВИЋ 2000: 283-294; 2014: 175; ЛАзИЋ 2006: 649; Костић 2016: 44-52; 2017: 48-53; СтАнковит 2018: 141-143). Његовим залагањем и уз помоћ личних финансијских средстава (делимично или у целости), у време између 1815. и 1839. подигнуто је више стотина храмова и обновљено више манастира (Вујић 1901; 1902; МАРКовић 1942: 121-130; КАШИЋ 1960: 267-271; СТРАњАКОВИЋ 1960: 262-267; КОСТИЋ 2016: 47-48).

У време прве владавине кнеза Милоша Обреновића Србија је била највеће градилиште на Балкану (КолАРић 1959: 15-23). За важне градитељске подухвате, попут изградње првих профаних објеката различите намене и храмова, кнез је настојао да омогући најбоље градитеље и довољну физичку снагу. Будући да локалних градитеља у том периоду није било довољно да задовоље потребе тржишта, довођени су мајстори из околних области, претежно из јужних крајева Балкана, који су још увек били део Османског царства (КолАРит 1959: 13-14; Класищизам 1966: 5, 26-31; Костит 2006: 226-241; НЕстоРОвић 2006: 26, 38). Највећи број градитеља сакралних објеката у време прве владавине кнеза Милоша долазио је са простора данашње Македоније - из Охрида, Битоља, Крушева, Велеса, Вранеша, као и из Осата у Босни и Херцеговини, док је број локалних градитеља био мали, а градитељима са територије Хабзбуршког царства у ово време готово да нису поверавани послови везани за изградњу храмова (КолАрић 1959: 13, 24-28; Класицизам 1966: 26-35). ${ }^{1}$ Градитељи са југа Балкана градили су, осим у Србији, православне храмове широм Балкана припадајући јединственом балканском културном моделу (MAKULJEVIĆ 2004: 387-390; МАКуљЕвић 2006: 22-29). Овај културни модел, негован међу хришћанима у Османском царству, био је прихваћен у Србији након Другог српског устанка (1815). После Хатишерифа 1830. године, прихватањем одређених елемената европске културе, балкански културни модел прераста у особено домаће стање у култури (МАкуљевић

\footnotetext{
${ }^{1}$ Италијан Ђузепе ди Антонио из Лугана је у време прве владавине кнеза Милоша био најчешће ангажовани странац на сакралним објектима и то ради кречења и молерисања, а такође је био мајстор за штукатуру. Радио је у црквама у Крагујевцу, Јагодини, Сибници, Чокешини и Боговађи, а вероватно и на многим другим које још нису идентификоване.
} 
2006: 38 -45). ${ }^{2}$ Носиоци овог културног модела у Кнежевини Србији, поред кнеза Милоша и чланова његове породице, била је црквена, трговачка и устаничка елита, управо онај слој српског друштва који се јавља као ктитор храмова или иницијатор њихове градње. Овакав културни контекст био је погодно тле за прихватање градитеља са југа Балкана и њихову доминацију у сакралном градитељству младе Кнежевине Србије. Врхунац њихове градитељске делатности био је до средине XIX века. Са променом власти 1842. године, доласком кнеза Александра Карађорђевића и уставобранитеља, са све јачим усвајањем европског културног модела и реорганизацијом кадровске структуре државних институција, балканске градитеље постепено потискују архитекте и инжењери школовани у европским центрима, којима се поверавају места у државним институцијама и пројектовање, надзор и изградња сакралних и профаних објеката (Класииизам 1966: 33-35; НестоРовић 2006: 91-105; Костић 2016: 241-247).

Своје градитељске и мајсторске вештине градитељи који су потицали из Османског царства стицали су у оквиру тајфи, што је био вид едукације карактеристичан за османски Балкан. ${ }^{3}$ Грађа о еснафима показује да је унутрашње уређење тајфи било строго прописано, хијерархизовано и да је напредовање у занату било постепено (ЂорЂЕвић 1925). За многе тајфе било је особено да су биле породичног карактера и да се знање и умеће преносило са колена на колено, те да су своја градитељска знања штитиле од других, конкурентских тајфи, стварајући сопствене градитељске тајне симболе и језик (ПоПОВСКИ 1976: 198-208; МИЛОСАВљЕВИЋ 2000: 50-52; МАКУљЕВИЋ, КОСтит 2020: 25, 32).

Међу градитељима који су са југа Балкана, углавном из Охрида, Битоља Крушева и Велеса, долазили у Кнежевину Србију и у време прве владавине кнеза Милоша учествовали у изградњи и обнови храмова, били су: Коста Димовић, Андрија Сотировић, Јања Михајловић, Никола Ђорђевић, хаџи Никола Живковић, Димитрије Сотировић (Сотир), Настас Стефановић и Сима Вироња. Неки од њих наставили су да оправљају и граде сакралне објекте и касније, током пете и шесте деценије XIX века, када им се прикључују и други градитељи из јужних области Балкана, попут: Настаса Ђорђевића, Настаса (Анастаса/Тасе) Наумовића, Петра Ђорђевића, Јована Вељковића, Петра Николића и Андреје Дамјанова (Костић 2016: 234-241). Од 1815. до 1839. године у Кнежевини раде и мајстори из Старог Влаха и Вранеша, попут Мирослава Буљугије и Новака (КолАРић 1959: 19, 26). Друга доминантна градитељска струја која је подизала и обнављала храмове у Србији, већ након Другог српског устанка 1815, долазила је из Осата у Босни и Херцеговини (МилосАвљЕвић 200о: 15-151).

2 Овај културни модел представља својеврсну фузију балканског и европског културног модела и имао је за циљ да Кнежевину Србију културолошки јасно одвоји од политичког другог - Османског царства и Хабзбуршке монархије. О томе више: МАкуљЕвић 2006: 38-45.

3 О томе како су изгледали процеси образовања градитеља на Балкану током XIX века сведочи заоставштина једног од најпродуктивнијих међу њима, Андреје Дамјанова. О томе вид. више у: МАкуЉЕВИЋ 2008: 25-27. 
Међу најпродуктивнијим осаћанским тајфама била је тајфа Милутина Гођевца (МилоСАвљЕВИЋ 2000: 136-150). О приватним животима, пореклу, образовању и опусу ових градитеља мало се или нимало зна. Њихова имена доводе се у везу са градњом појединих цркава углавном захваљујући сачуваној архивској грађи, што не искључује могућност проширења њиховог градитељског опуса везаног за сакралну архитектуру на тлу Кнежевине Србије идентификовањем нових дела у будућности.

У време прве владавине кнеза Милоша Обреновића ови градитељи дизали су сакралне објекте који су по својој типологији били различити. Ова различитост била је условљена политичким, културним, друштвеним и економским оквирима. Између 1815. и 1830. године, сакралним градитељством Србије доминирају цркве брвнаре због лакоће, брзине и ниских трошкова њихове градње (ПАвловит 1962; 1994: 21-37; Вујовић 1986: 102-108; Костић 2016: 175-184). Као репрезентативнији тип објеката подижу се једнобродни подужни храмови мањих димензија, без купола и звоника, грађени од чврстог материјала, са правоугаоним или полукружним певничким просторима, најчешће видљивим споља, са припратама или без њих (Вујовић 1973: XI-XII; 1986: 102; НЕстоРОвић 2006: 26-27, 119-121, 123-132). По својим архитектонским концепцијама, ови типови храмова одговарали су балканској сакралној архитектури тог времена. Након добијања Хатишерифа 1830. и верских слобода њиме загарантованих, долази до интензивнијег усвајања средњоевропских архитектонских схватања, те се прихвата модел православног храма са простора Карловачке митрополије, који подразумева једнобродну подужну грађевину са барокним звоником на прочељу. Звоњава звона и подизање звоника било је у то време симбол новостечене слободе и зато је изградња храмова са звоником била од идеолошког значаја за државу и цркву (СТРАњАКОВИЋ 1960: 266-267; КОСтић 2016: 50). Изградњом прво придворне Топчидерске цркве (1834), а затим и Саборне цркве у Београду (1837-1840), овај архитектонски тип храма бива општеприхваћен и доминантан у сакралној архитектури Кнежевине, подржаван и промовисан од стране црквених и државних власти од четврте деценије, па готово докраја ХIX века (Вујовит 1986: 110-123; Несторовић 2006: 26, 121-122, 132-148; МАКУљЕвИЋ 2014: 175; Костић 2016: 174-175, 191-205). Градитељи сакралних објеката који раде у време између 1815. и 1839. године прихватали су и задовољавали захтеве тржишта и наручилаца, што је утицало на то да њихове опусе управо чине храмови различитих архитектонских концепција и стилских одлика. Таква „прилагодљивост” градитеља који потичу из различитих области Балкана, сведочи о њиховој доброј упућености и градитељској вештини, која је у старијој историјскоуметничкој литератури била занемаривана.

Међу градитељима који су са југа већ 1815. дошли на територију устаничке Србије био је Коста Димовић из Охрида. Осим што је познато да је у Србију дошао из Охрида, нису познати други подаци о његовом животу и образовању. Прво познато његово градитељско остварење у Србији била је црква у Бресници код Краљева коју подиже 1815. године (Класицизам 1966: 28; Несторовић 2006: 119). У време између 1827. и 1831. године подиже Цркву Светих апостола Петра и Павла у Шапцу (Класииизам 1966: 28; 


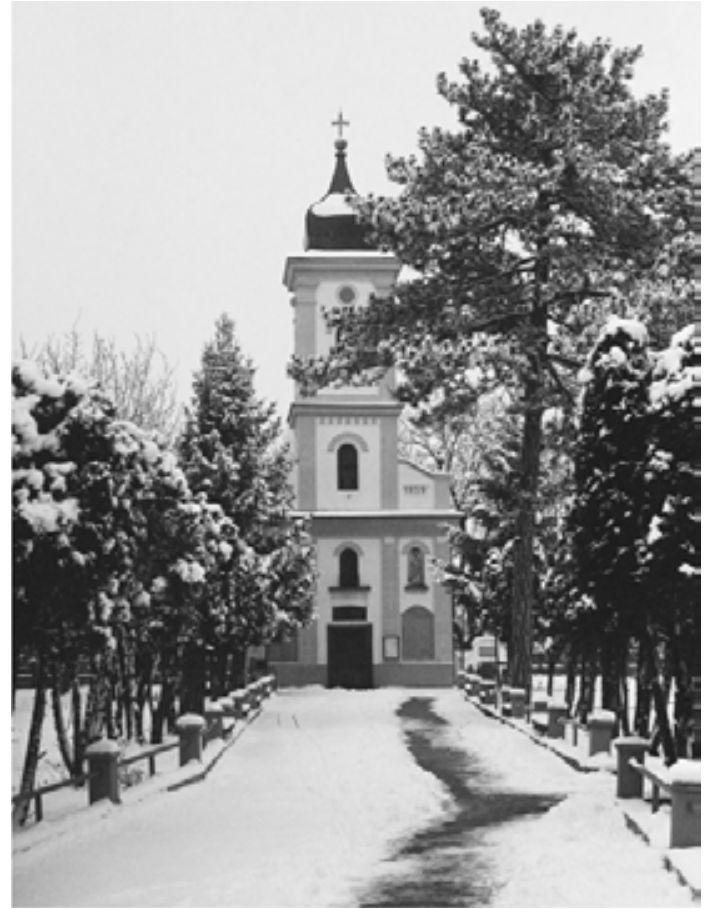

Сл. 2. Црква у Варварину, Јања Михајловић Мали и Никола Ђорђевић, 1825.
Вујовић 1986: 111). Године 1835. започео је градњу Цркве Покрова Пресвете Богородице у Ваљеву (Класицизам 1966: 28; Вујовић 1986: 112; Несторовић 2006: 134). Из писма Јеврема Ненадовића кнезу Милошу, с почетка 1833. године, сазнаје се да је жеља житеља Ваљева била да за градњу цркве ангажују Јању Михајловића, или Хаџију (хаџи Николу Живковића). Како је из Београда стигао одговор да су оба мајстора заузета, Јеврем Ненадовић 1833. године обавештава кнеза Милоша да је за изградњу цркве у Ваљеву нашао неимара Косту Димовића, који се уговором обавезао да ће подићи ваљевачку цркву од тврдог материјала, у свему боље него шабачку (АC-КК, IX, 1833, 394; НеСторОвић 2006: 134). Архивска грађа показује да је већ 1836. године Коста Димовић остао без овог посла јер је, по жељи кнеза Милоша, овај посао поверен другом градитељу, Димитрију Сотировићу (АС-КК, IX, 1836, 498; Класицизам 1966: 295). Разлози за овакву кнежеву одлуку остали су

непознати, те се само може претпоставити да кнез није био задовољан, или његовим радом, или ценом.

Међу градитељима који су са југа Балкана дошли у Кнежевину Србију били су и Јања Михајловић и Никола Ђорђевић. Они су били међу најангажованијим неимарима током прве владавине кнеза Милоша Обреновића. Није познато одакле су дошли у Србију, а на њеној територији остварили су значајан опус у домену сакралне и профане архитектуре (ПЕтровић 1899: 127, 170, 213, 553, 599; ПАвловић 1955: 302; КолАРић 1959: 20-21, 25; Класицизам 1966: 27-28; Вујовић 1986: 141; Несторовић 2006: 53-61; МАневић 2008: 289; МитровИЋ 2008: 53-54, 93-96; МАКУљЕВић 2014: 159, 167-168, 175). Јања Михајловић био је доста цењен градитељ, познат још и као Јања Мали, Јања Цинцарин или Јања Гагрица. Познато је да је тридесетих година XIX века имао своју зидарску тајфу од тридесеторо људи, од чега осамнаест мајстора, две калфе и три чирака (ЂорЂЕвић 1922: 55-57). Јања Михајловић и Никола Ђорђевић радили су углавном заједно, предузимајући неколико послова истовремено. Јављају се први пут 1822. године када граде цркву у Карановцу (Краљеву) на захтев кнеза Милоша, а затим граде цркве у Рибнику 1823. и Варварину 1825. године (сл. 2) (АС-МПс, 1844, ф. VI, р. 26; ПЕТРОвИЋ 1899: 127, 170, 213, 553, 599; Класицизам 1966: 27-28; МАКУљЕВИЋ 2000: 290-291; 
БогДАНОвИЋ, Новчић 2000: 297; НЕСторовић 2006: 130). Такође 1825. године раде на обнови манастира Рукумије, затим на обнови цркве и конака манастира Раче 1826. и подижу цркву у Свилајнцу 1827. године (Петровић 1899: 127, 170, 213; Класииизам 1996: 27-28; Несторовић 2006: 132). По преласку у Београд раде Конак кнегиње Љубице 1829. године и цркву са конацима манастира Раковице 1824-1829. године (сл. 3) (Петровић 1899: 553; Класицизам 1966: 179; Џелеьић 1969: 110-111; Вујовит 1973: 264; 1986: 108; МАКУљЕВИЋ 2014: 159). ЊИХов заједнички рад је и Стара црква Светог Марка на Ташмајдану у Београду (сл. 4), подигнута 1832-1833. на месту са ког је 1830. године прочитан Хатишериф (Несторовит 2006: 129; МАКУљЕВИЋ 2014: 167-168). Јања Михајловић почиње са градњом Конака у Топчидеру 1831 . године, а приликом грађења Топчидерске придворне цркве 1832-1834. године придружио му се Никола Ђорђевић (ПЕтровић 1899: 599; НЕСТОРОвић 2006: 133-134; МитРовић

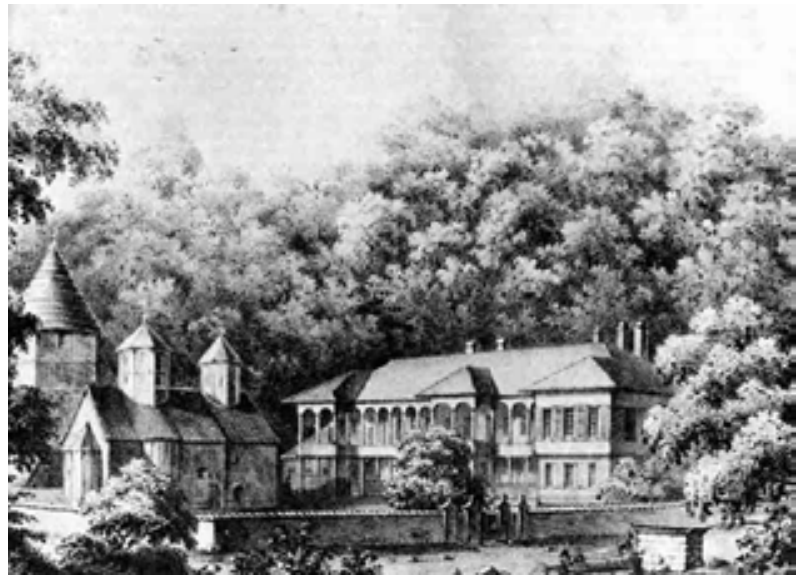

Сл. 3. Конаци манастира Раковице, 1824-1829.

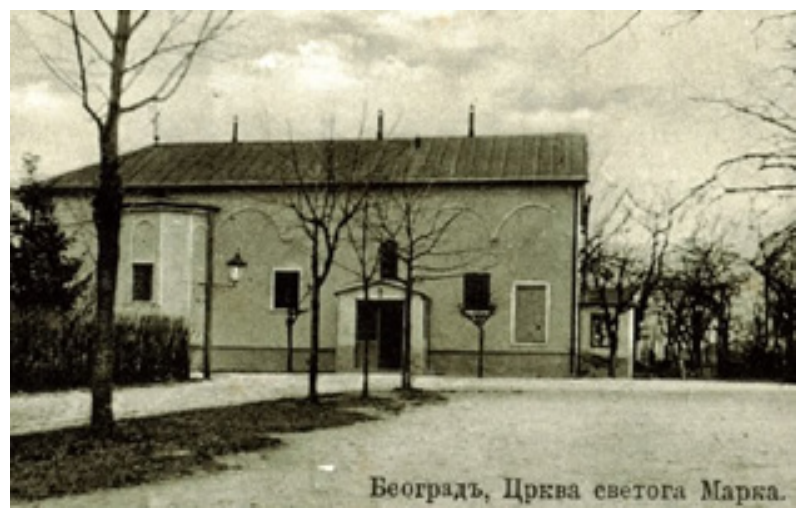

Сл. 4. Стара црква Светог Марка на Ташмајдану у Београду, Јања Михајловић Мали и Никола Ђорђевић, 1832-1833. 2008: 60-63, 92-96; МАКУљЕВИЋ 2014: 175). Јања гради и цркву у Остружници 1833. године (Петровић 1897: 722; Вујовић 1973: 226; НЕСторовић 2006: 131-132), а потом предузима обнову цркве у Зајечару и доградњу цркве у Ваљеву 1837. године, што је уједно за сада његов последњи познати посао у Кнежевини (АС-КК, IX 1837, 593; Класицизам 1966: 28, 339-341; НеСторовић 2006: 134-137). Архивска грађа указује на то да је Јања био ангажован у неком својству и на пословима изградње шабачке цркве током 1829. године. Он тада тражи да из Вишњице допреми камен за градњу храма (ЏЕлеьић 1969: 107-108). Могуће да је, због других уговорених послова, допремање материјала био једини његов ангажман у изградњи шабачке цркве. Осим заједничких дела са Јањом, за сада није утврђен Николин самосталан рад на изградњи сакралних објеката. 
Један од најистакнутијих неимара у Кнежевини Србији био је хаџи Никола Живковић. Познато је да је рођен 1792. године у Крушеву или Водену у Македонији, као и то да је умро 1870. године у Београду (Несторовит 1937: 13-14, 19-20; 1974: 143; 2006: 54, 129, 133; КолАРИЋ 1959: 19-20; Класицизам 1966: 30-31; ЏАмБАзОвски 1984: 506; МАНЕВИЋ 2008: 131; ВИЋЕНТИЋ 2010: 319-337; ЂурИЋ ЗАмОЛО 2011: 126-131). Претпоставља се да се школовао у Солуну или у Атини, а време његовог доласка у Кнежевину Србију није за сада познато (Ђурић ЗАмоло 1981: 42; НЕсторовић 2006: 53). По доласку у Кнежевину, хаџи Никола Живковић врло брзо задобија поверење кнеза Милоша Обреновића и он му поверава изградњу и надзирање изградње најрепрезентативнијих грађевина у Београду у првој половини XIX века (НЕсторовић 2006: 54). Сматра се да су према његовим пројектима изграђени Конак кнегиње Љубице, Конак и црква у Топчидеру и Ђумрукана (Класицизам 1966: 30-31; Вујовић 1986: 108; Несторовић 2006: 53-54; Вићентић 2010: 321; МАкуљЕвић 2014: 99). Хаџи Николи Живковићу се приписују и планови конака и цркве манастира Раковице (Класицизам 1966: 30-31), Прве београдске касарне у Палилули 1837. године, Више женске школе, као и здања грађеног за кнежев двор 1829-1836. које је коришћено за потребе Министарства финансија (НЕсторовић 1937: 20; ПАвловић 1955: 280; СтАнојЕвић 1960: 177; Вићентић 2010: 321). У време власти кнеза Милоша Обреновића, хаџи Никола Живковић је био постављен званично за кнежевог личног мајстора (1834), за шта је примао и годишњу плату у висини од 3000 гроша. Као повереник кнеза Милоша, за време његове владавине, осим задобијеног угледа успео је да створи и завидан иметак (Вићентић 2010: 322). Тек након доласка Томе Вучића Перишића у Београд и његовог преузимања улоге руководиоца државне изградње, као и личних сукоба са њим, хаџи Никола Живковић губи неке од стечених привилегија. Након кризе која је обележила његову градитељску активност и позицију у друштву, 1837. хаџи Никола добија поново место у државној служби као „надзиратељ над мајсторима”. Ова функција трајала је до одласка кнеза Милоша са власти 1839, а и званично му је укинута 1841. године (Вићентић 2010: 323-324). По одласку Обреновића са власти, 1842. године се пресељава у Земун пошто је био прогнан као њихов присталица, а 1843. године засигурно се вратио у Кнежевину пошто се утврдило да није противник уставобранитељског режима. Тада је по налогу кнеза Александра Карађорђевића радио на изградњи Среске куће у Тополи (Вићентић 2010: 325-330). По Милошевом повратку на власт 1859. године хаџи Никола Живковић ради при Министарству грађевина као „надзиратељ правителствених грађевина" све до смрти, након чега је ова служба укинута (Ђурић ЗАМОЛО 1981: 42; МАНЕВИЋ 2008: 131).

Хаџи Никола Живковић је током свог живота у Кнежевини Србији изградио већи део државних зграда и надзирао већину објеката међу којима су биле и цркве. Претпоставља се да су његови планови били ти по којима су стару Цркву Светог Марка на Ташмајдану, придворну цркву у Топчидеру, конаке и цркву манастира Раковице подигли градитељи Јања Михајловић и Никола Ђорђевић, но до опсежнијих истраживања не треба искључивати ни њихов самостални удео у плановима тих 
објеката (Несторовић 2006: 129, 133). Један од Живковићевих радова везан за сакралну архитектуру, који се на основу сачуване архивске грађе сасвим поуздано везује за његово име, јесте израда плана и изградња звоника на Цркви Светих апостола Петра и Павла у Шапцу (Вићентић 2010: 330-333). ${ }^{4}$ Шабачка црквена општина је склопила са хаџи Николом уговор око подизања звоника 2. јуна 1851. године. Како је током градње са наручиоцима долазило до неслагања, израђен је нов план у Министарству грађевина, по коме је звоник завршен тек 1858. године (Вићентић 2010: 331-333).

Са југа Балкана у Србију је дошао и Цинцарин Димитрије Сотировић (Сотир) (Класииизам 1966: 29; СРедојЕвић 2004: 107-109). Познато је да је 1834. године имао тајфу од петнаест зидарских радника и да је учествовао у изградњи Ђумрукане (Класииизам 1966: 29). На основу сачуване преписке Јеврема Ненадовића са кнезом Милошем од 14. априла 1836. године, сазнаје се да је Сотировић дошао са својим радницима у Ваљево да зида цркву. У погодби се обавезао да цркву зида по угледу на пожаревачки храм, по цени од 15.000 гроша чаршијских (АС-КК, IX, 1836, 499; Класицизам 1966: 295, 297-298; Несторовић 2006: 136). Због пуцања зидова и сводова током градње, Сотировић је посао на ваљевачкој цркви препустио Јањи Михајловићу на захтев кнеза Милоша, о чему сведоче сачуване преписке (Класицизам 1966: 339341; Несторовић 2006: 136). Осим напола остављене ваљевачке цркве, Сотировић је допола градио и Цркву Светог Димитрија у селу Брезни 1836. године чији је ктитор био кнез Милош (Класицизам 1966: 308). Из непознатих разлога, по кнежевој наредби, Сотировић напушта градњу цркве и уступа је Настасу Стефановићу (AC-КК, XXVI, 1837, 187; Класицизам 1966: 29). О томе сведочи преписка између капетана Среза црногорског Петронија Андрејевића са кнезом Милошем, од 16. маја 1837. године (Класициизам 1966: 335). Као што је већ поменуто, Димитрије је кратко време био ангажован и на довршавању цркве у Ваљеву, пошто је посао преузео од Косте Димовића (Класииизам 1966: 28).

Пореклом са југа Балкана је и Настас Стефановић, познат још и као Настас Цинцарин. Био је један од продуктивнијих неимара који је дуго радио на простору Кнежевине Србије. Није познато када је дошао у Србију, а прво његово идентификовано дело је касарна у Пожаревцу коју подиже 1834. године (Класицизам 1966: 29, 236). Осим завршетка градње Цркве Светог Димитрија у Брезни (сл. 5), коју преузима од Димитрија Сотировића 1837. године (АС-КК, XXVI, 1937, 187), подигао је Цркву Светих апостола Петра и Павла у Грошници 1835. године. Године 1836. склапа уговор за изградњу Цркве Светог Николе у Брусници (сл. 6), чији је ктитор био Јован Обреновић (Ктасицизам 1966: 29; 306). На основу преписке између Арсенија Андрејевића и Јована Обреновића од 28. јуна 1836. и 13. јула 1837. године, познато је да је неимар Настас цркву у Брусници изградио докраја 1837. године (Класицизам 1966: 306, 347-348).

4 Многи храмови који су изграђени и чија изградња је започета пре доношења Хатишерифа 1830. године, добијају након тих година звонике. Ова пракса дограђивања звоника била је устаљена оквирно до седме деценије XIX века (КОСтић 2016: 199-200). 


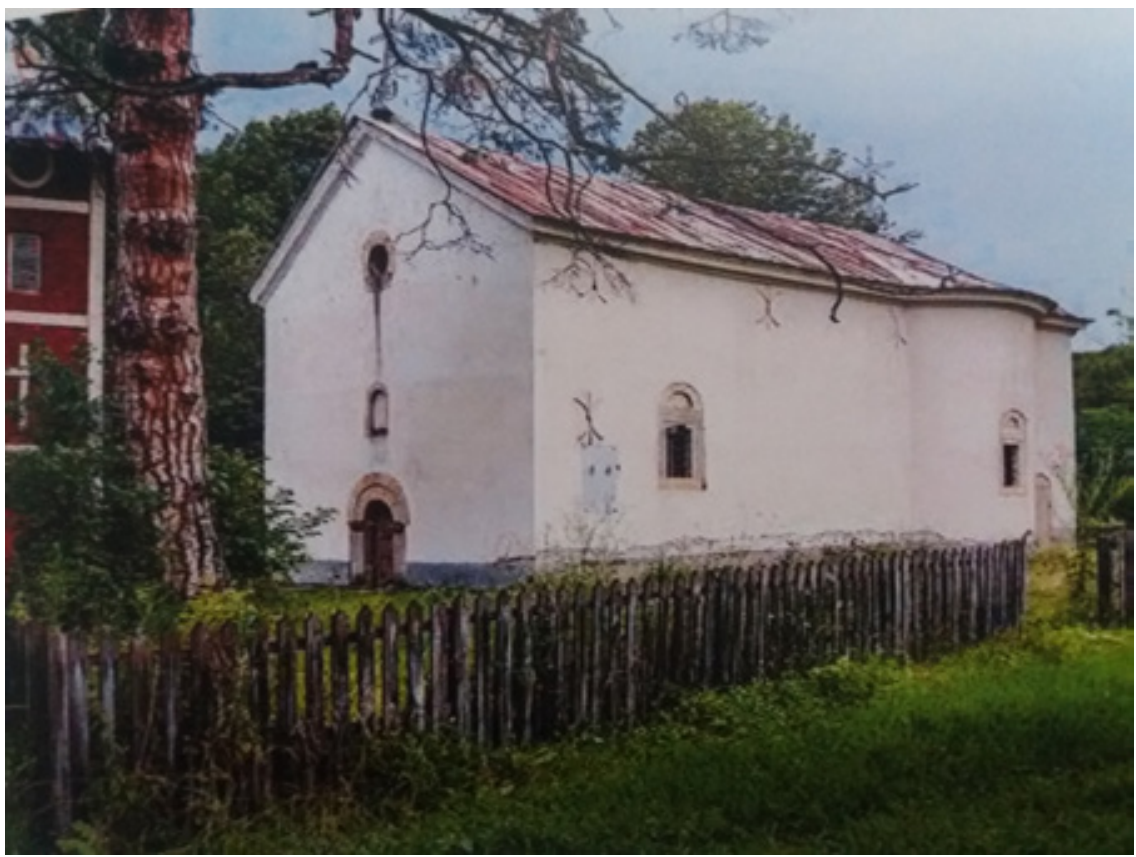

Сл. 5. Црква Светог Димитрија у Брезни, Настас Стефановић, 1837.

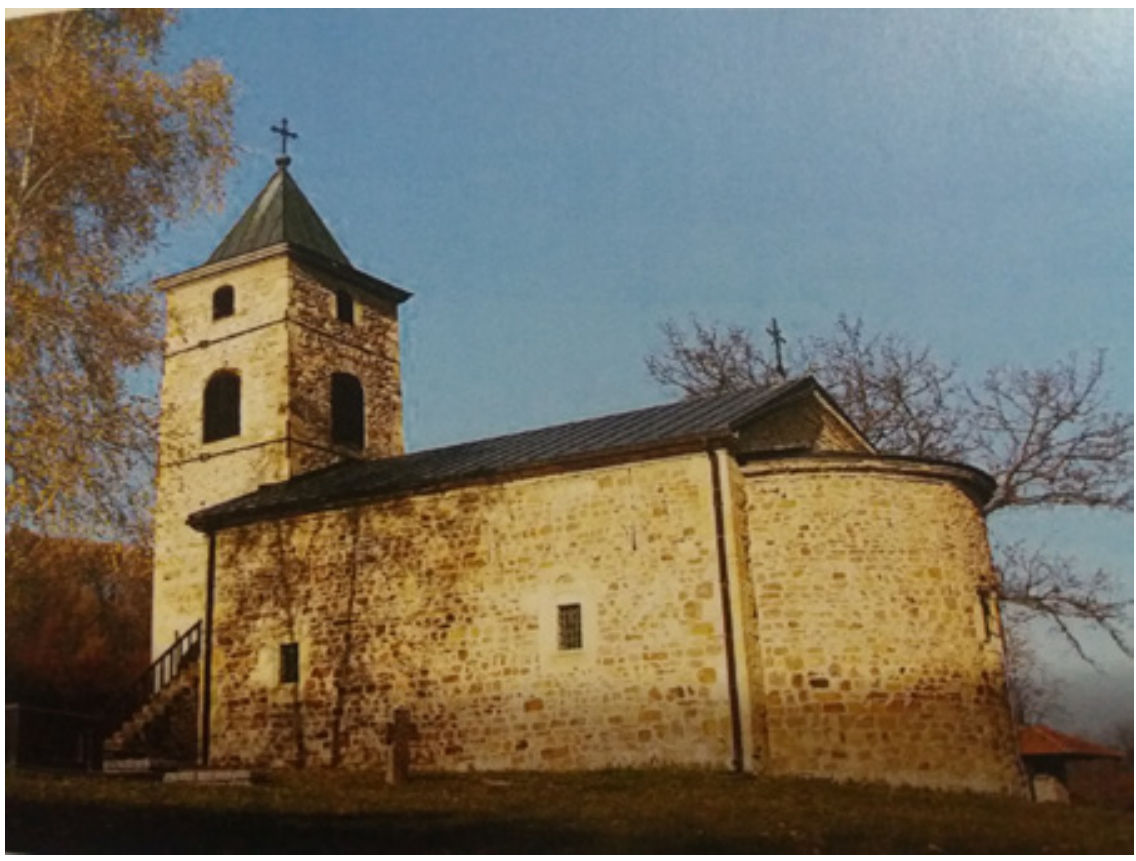

Сл. 6. Црква Светог Николе у Брусници, Настас Стефановић, 1836. 
Настас Стефановић је био доста ангажован приликом поправке неколико манастирских целина у време кнеза Александра Карађорђевића. Тако је 1841. године вршио обнову католикона и конака манастира Враћевшнице (АС-МБ, 1840, No. 318; АС-МПс, 1841, Ф. 1, р. 31; Класицизам 1966: 31), градио конаке манастира Студенице 1843-1844. године (АС-МБ, 1839, No. 342), предузео обнову цркава и конака манастира Манасије и Раванице 1844. године (Класицизам 1966: 31), а био је ангажован и на радовима у манастиру Витовници (АС-МБ, 1841, No 36, No 184, No. 420, No 798; Ђокић, Поповић 2005: 81-82).

На изградњи сакралних објеката у Кнежевини Србији ради и Андрија Сотировић, пореклом Цинцарин. За сада није познато да ли је овај градитељ био у сродству са већ поменутим Димитријем Сотировићем. Андрија је био главни мајстор на обнови цркве Заове предузете 1838. године (Класицизам 1966: 29; Ђокић, Поповић 2005: 97-99). Може се претпоставити да је Андрија Сотировић пре радова на манастиру Заови са својом тајфом градио Цркву Светог Николе у Алексинцу, од 1836. до 1837. године. Архивска грађа сведочи да је оданде позван у манастир Заову да надзире дотадашње мајсторе који су радили на цркви (Класицизам 1966: 345-347; Ђокић, Поповић 2005: 99). У рапорту дунавско-тимочког команданта, пуковника Стефана Стефановића Тенке, кнезу Милошу, од 6. јула 1836. године, сазнаје се да ће мајстори који су градили Бањску цркву5 по завршетку посла доћи у Алексинац да тамо почну градњу цркве са звоником. Стефановић даље извештава кнеза Милоша да ће мајстори подићи алексиначки храм са торњем, према топчидерском храму, који су већ видели, по цени од 5000 гроша (АС-КК, XIX, 347; Класицизам 1966: 306-307). С друге стране, мајор Петар Илић је 16/28. октобра 1837, издао уверење у Пожаревцу да је мајстор Андрија Сотировић са „дружином својом” радио на манастиру Заови, те се његово ангажовање у послу не може довести у сумњу (Ђокић, Поповић 2005: 99). Из Тенкиног писма, упућеног кнезу Милошу 2. маја 1838. године, сазнаје се да су мајстори који су зидали алексиначку цркву стигли у Кладово да подигну нову цркву о кнежевом трошку (Класицизам 1966: 370-371). С обзиром на то да је црква у Кладову грађена знатно касније, од 1856. до 1862. године, мало је вероватно да се њена изградња може приписати Андрији Сотировићу до опсежнијих истраживања.

У време прве владавине кнеза Милоша, из Охрида у Србију долази Сима Вироња. Тачно време доласка се не зна, но познато је да је 1837. године склопио уговор са Јованом Обреновићем у вези са зидањем цркве у Ивањици (сл. 7) за суму од 13.000 гроша (Класииизам 1966: 30, 353-354).

На територији Кнежевине Србије радили су и мајстори пореклом из Старог Влаха и Кичева. Међу њима је Мирослав Буљугија, неимар из Вранеша, из Старовлашке нахије, који је 1823. године добио дозволу да са својим људима ради на простору

5 За сада није сигурно на коју се Бању мисли, манастир Бању или, вероватније, стару цркву у Соко Бањи, подигнуту о трошку кнеза Милоша 1836. године. Даља архивска истраживања расветлиће ово питање. 


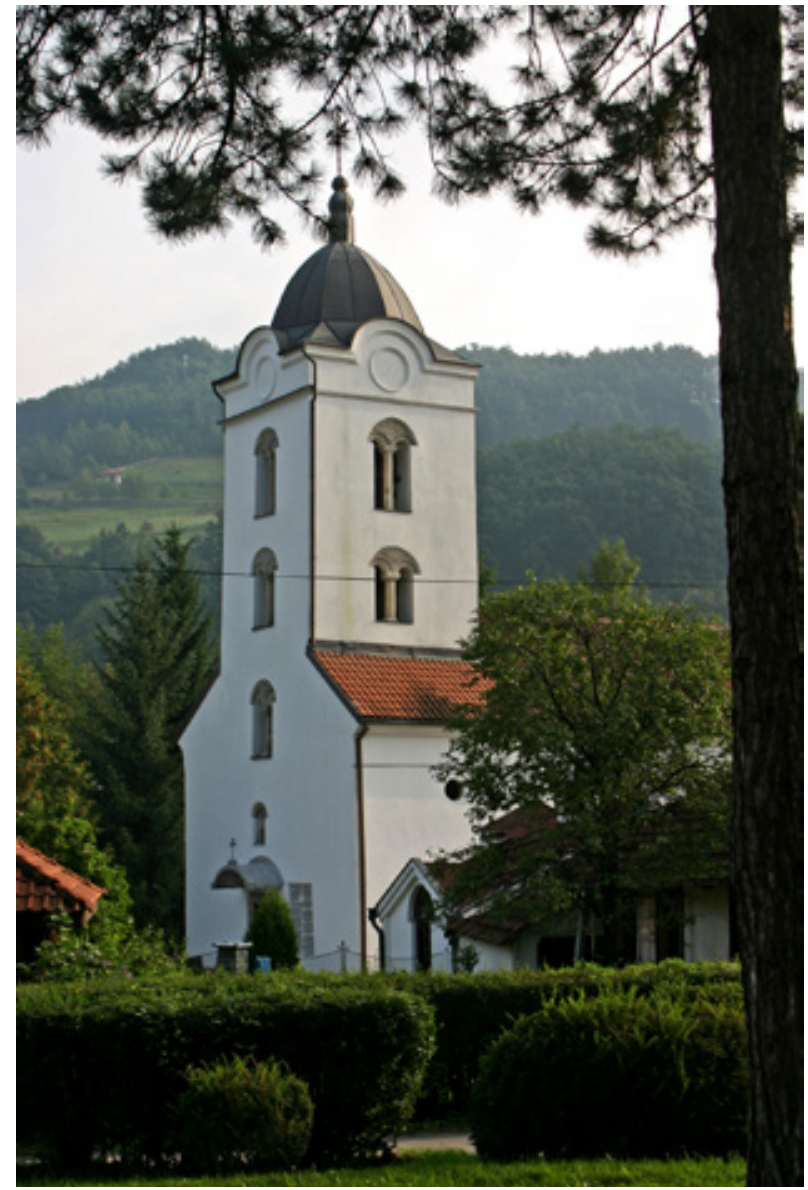

Сл. 7. Црква Светог цара Константина и царице Јелене у Ивањици, Сима Вироња, 1837-1838.
Кнежевине (КолАРиЋ 1959: 26). Познато је да се 1823. године Буљугија договара са игуманом манастира Каленића Пајсијем да изгради конаке о трошку кнеза Милоша (Класицизам 1966: 28). ${ }^{6}$ Међу овим мајсторима је и мајстор Новак из Вранеша који је обновио манастир Дабриловину 1827. године (НЕстоРОВИЋ 2006: 120).

Поред неимара који у Кнежевину Србију долазе са југа, један број зидарских дружина долази из Осата у Босни и Херцеговини (МиЛОСАВљЕВИЋ 2000: 15-151). Након Другог српског устанка, породице неимара из Осата насељавале су се у селима у околини Крагујевца, Ваљева и Ужица, одакле су радиле по читавој Кнежевини (ПАвловић 1962: 38-39; МИЛОСАВљЕВИЋ 1991: 67; 2000: 83-84). Мајстори Осаћани су обележили сакрално градитељство Кнежевине Србије углавном подизањем цркава брвнара, преневши притом специфичан начин градње и особену декорацију карактеристичну за објекте које су подизали по родној Босни и другим деловима Балкана. Већина осаћанских неимара који су градили цркве брвнаре по Кнежевини Србији остала је именом непозната. Нека су позната по предању или урезивању на појединим местима у храму. Тако је, по предању, цркву брвнару у Вранићу 1823. године градио извесни Сима из Осата, а Никола Димитровић урезао је своје име на вратима исте године (ПАвловић 1962: 39). Цркву брвнару у Смедеревској Паланци изградио је 1828. Петар Андрејевић (ПАвловић 1962: 39). Осаћанин Митар Новаковић је за суму од 500 гроша и 20 пара подигао цркву брвнару у Цветкама код Краљева (ПАвловић 1962: 39). Позната су имена и градитеља Лазара, потписаног у цркви брвнари у Рачи Крагујевачкој, као и Димитрија, Марка,

${ }^{6}$ Његов удео у овом подухвату треба детаљније испитати. 
Стојадина и Станојла са таванице трема цркве брвнаре у Павловцу (ПАвловит 1962: 39). Осаћанске неимаре доста је ангажовао кнез Милош при обнови или изградњи монументалнијих цркава од трајног материјала. О њиховом ангажовању широм Кнежевине сведочи и сачувана архивска грађа. Тако, кнез Милош шаље Стефану Стефановићу Тенки осаћанске неимаре за оправку поречке цркве која је „препукла" (ЂорЂЕвић 1925: 38-39). На оправци цркава у Пожаревцу и Рукумији такође раде осаћански неимари. О томе сведочи и писмо које је кнез Коца Марковић послао из Пожаревца кнезу Милошу у Крагујевац, молећи га да му пошаље „још 15 дунђера за цркве пожаревачку и рукомијску... од налазећих се ту Осаћана" (ЂорЂевић 1925: 47).

Међу најпознатијим осаћанским тајфама које граде цркве по Кнежевини Србији у време прве владавине кнеза Милоша Обреновића била је тајфа Милутина Гођев-

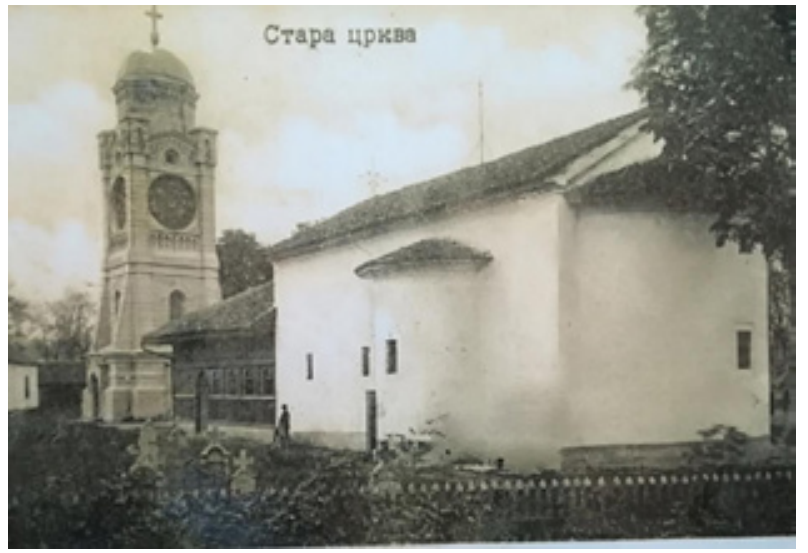

Сл. 8. Стара црква у Крагујевцу, Милутин Гођевац, 1818.

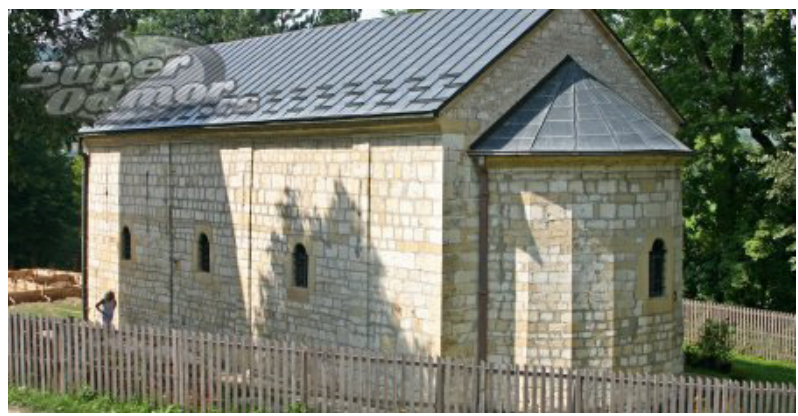

Сл. 9. Црква у Горњој Добрињи, тајфа Милутина Гођевца (Ђура и Алекса Гођевац), 1822. ца (МиЛОСАВљЕВИЋ 2000: 136-150). Милутин Гођевац је из Осата прешао у Србију још у време Карађорђа, а био је и један од првих, изузетно ангажованих грађевинара и у време кнеза Милоша. Обновио је манастир Боговађу 1816. године, придворну цркву у Крагујевцу (сл. 8) и цркву у Јагодини 1818, затим у Савинцу 1819, Осипаоници 1826, Шетоњама 1829. године, а радио је и на обнови манастира Чокешине, где је подигао цркву у време између 1820. и 1823. године (ВУјОвИЋ 1986: 108; МиЛОСАВљЕВИЋ 2000: 137-142, 144-145; НЕСтОРОВИЋ 2006: 123; Костић 2017: 36-37, СтАнковић 2018: 132). Као чланови његове градитељске тајфе радили су његови синови Ђура, Алекса и Петар. Ова тајфа градила је храм у Горњој Добрињи (сл. 9), који је 1822. године кнез Милош подигао у спомен на свог оца Теодора

7 Ова имена, као и имена градитеља поменутих цркава брвнара, треба узети са опрезом јер су се и приложници градње и кметови такође могли наћи као потписници. Таква пракса је била уобичајена при изградњи храмова подигнутих од трајног материјала, те је не треба искључити ни као могућност у случајевима потписа на црквама брвнарама. 
(Класииизам 1966: 225; МилосАвљЕвић 2000: 142-143). Неимари из Гођевчеве тајфе обновили су и манастир Грабовац у време између 1820. и 1824. године (МиЛОСАвљЕВИТ 2000: 143-144). ${ }^{8}$

Синови Милутина Гођевца, Ђура и Алекса, такође су били познати неимари. Њихово заједничко остварење била је црква у Бранковини подигнута између 1829. и 1830. године (Класищизам 1966: 26-27; ВујОвиЋ 1986: 112; МиЛОСАВљЕВИЋ 2000: 148). О њИма као градитељима цркве сведочи запис у унутрашњости храма. Сматра се да је и храм у Гучи дело ове двојице градитеља јер је по концепцији сличан цркви у Бранковини, а по архитектонском украсу близак грађевинама које је градио Милутин Гођевац (МилосАвљЕвић 2000: 149). Од двојице браће из породице Гођеваца познатији је био неимар Ђура Гођевац. Он је градио цркву у Паунима 1834. године (Класицизам 1966: 235-236). У време градње цркве у Паунима Ђура је радио на цркви у Ћуприји (АС-КК, 1834, 437; Класицизам 1966: 235; МилосАвљевић 2000: 136). Неимарској породици Гођевац припадао је и Петар, чија самостална градитељска остварења нису за сада позната.

Поред градитеља који су долазили у Кнежевину Србију са простора Османског царства - са југа Балкана и из Осата, на њеној територији деловали су и локални градитељи. Већи део цркава брвнара у Кнежевини Србији подигли су именом непознати локални мајстори. Само у ретким случајевима сачувана су њихова имена. Тако су локални градитељи цркве брвнаре у селу Трњане код Неготина (сл. 10) Стојан и Станко познати захваљујући њиховом приложничком дару, икони Светог Георгија која је постављена на иконостас након изградње храма 1829. године (Ћировић 2012: 261). Међу градитељима за које се сматра да су родом из Србије био је неимар Веселин (Класицизам 1966: 27). Као сарадник Милутина Гођевца суделовао је у обнови манастира Чокешине 1820-1823. и цркве у Шетоњама 1829, а њему се приписује и обнова цркве у Шаторњи 1828. године (Класицизам 1966: 27). Један од познатијих локалних градитеља био је Тодор Петровић из Пожаревца који је подигао придворну цркву у Пожаревцу, ${ }^{9}$ као задужбину кнеза Милоша 1819. године (Несторовић 1974: 151; 2006: 125; ЛАзИЋ 2008: 18). Током 1824. изградио је цркву манастира Госпођин код Добре (Класииизам 1966: 27; Несторовит 2006: 121). Познато је да је он градио и цркву у Јарушници (Класицизам 1966: 27; Несторовић 2000: 125). ${ }^{10}$ Међу локалним градитељима био је и Петар Кондин, који је изградио стару Цркву Светог духа у Гроцкој 1828 , која је касније срушена зарад изградње нове, подигнуте 1883 . године (НестоРОвић 2000: 255). Чињеница да је знатан број локалних неимара остао именом непознат у великој мери отежава прави увид у значај локалних градитељских струја у развоју сакралног градитељства у периоду између 1815. и 1839. године.

\footnotetext{
${ }^{8}$ На месту ове цркве изграђена је 1894. нова црква: МилосАвљЕвит 200о: 143-144.

9 О могућим неимарима пожаревачког храма расправљају: ФЕЛДић 1992: 107; КАСАлИЦА 1997: 62; НЕСТОРОВИЋ 1974: 151.

10 Тодор Петровић је суделовао и на изградњи профаних објеката. Тако је познато да је био ангажован и при градњи Милошевог конака у Крагујевцу (НЕстоРовић 2006: 50).
} 


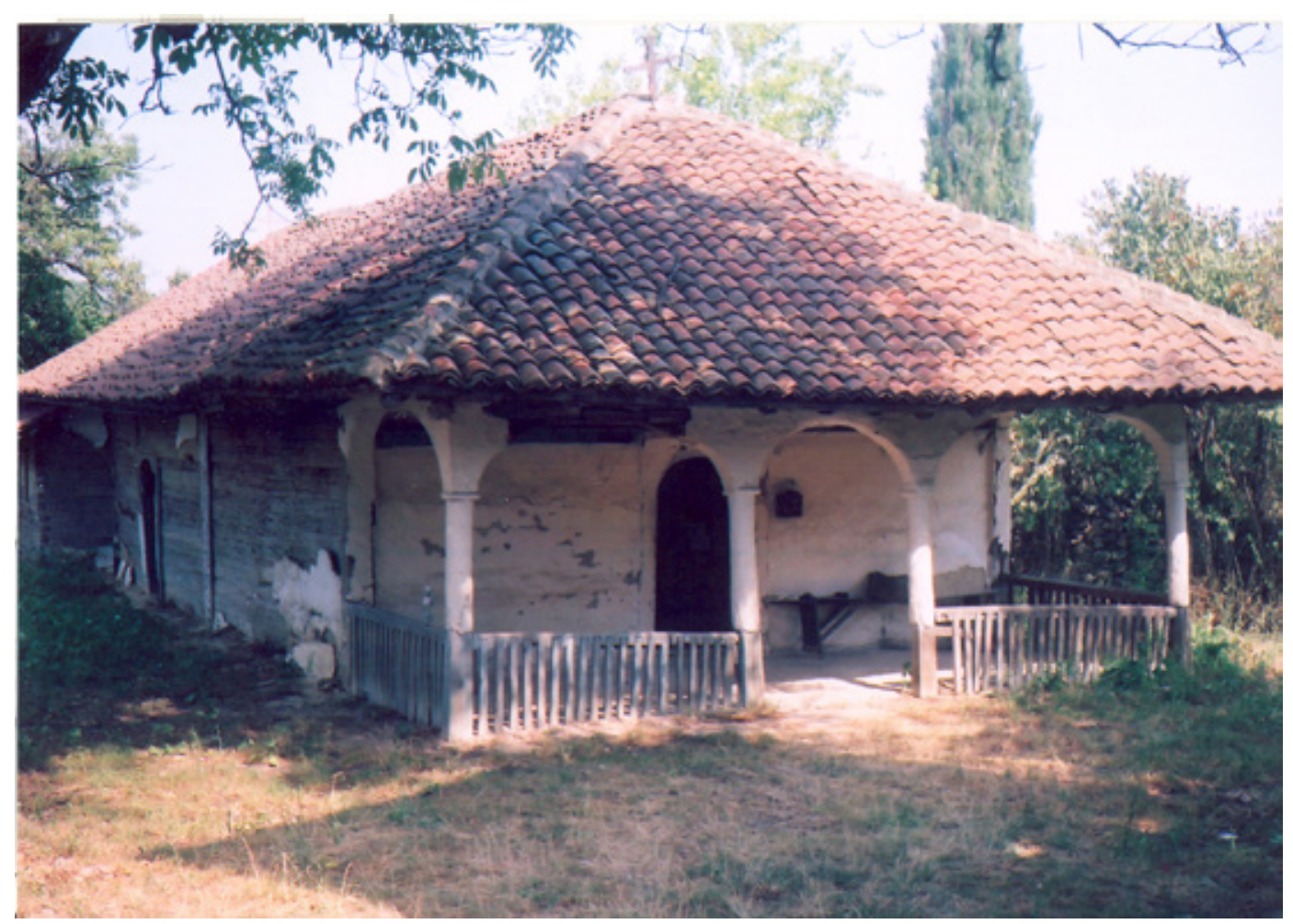

Сл. 10. Црква брвнара у селу Трњане у Тимочкој Крајини, Стојан и Станко, 1829.

За токове сакралног градитељства Србије у време прве владавине кнеза Милоша Обреновића, значајан догађај представља изградња Саборне цркве у Београду. Овај храм је својом архитектонском концепцијом и стилом градње требало да репрезентује ново политичко стање Србије и Цркве, настало након добијања Хатишерифа 1830. и Конкордата 1831. године, да уједно буде оличење просперитета, тежњи у култури, уметности и црквених реформи младе Кнежевине. Из ових побуда произлази одлука да се стари храм Светог архангела Михаила не обнавља, о чему се, почевши од 1831. године, интензивно размишљало, већ да се на његовом месту подигне нов (Вујовић 1986: 115-124; 1996: 54-57; МАКуљЕвић 2014, 130-131). Реализација ове идеје поверена је панчевачком архитекти Фридриху Адаму Кверфелду и његовом рођаку Францу Добију, који су између 1837. и 1840. године подигли цркву, према Кверфелдовим плановима (Вујовић 1986: 116-119; 1996: 48-51, 54-57). Након Саборне цркве, чији су пројектовање и изградња поверени градитељима из Хабзбуршке монархије, страним, школованим архитектима и инжењерима отворен је пут у Кнежевини Србији и у домену сакралног градитељства. 
Са променом власти 1842. године, доласком Александра Карађорђевића и уставобранитеља, променом културне политике у Кнежевини, те захваљујући доследнијим црквеним реформама митрополита Петра Јовановића, страни, школовани инжењери и архитекте преузимају примат у пословима из домена сакралне архитектуре, на тај начин постепено, али сигурно, потискујући балканске градитеље. Иако током пете, шесте и седме деценије XIX века значајно ангажовање у изградњи сакралних објеката остварују поједини градитељи из јужних области Балкана, попут Настаса Ђорђевића, Настаса (Тасе) Наумовића, Петра Ђорђевића, Јована Вељковића, Петра Николића и Андреје Дамјанова, њихов рад надзиру инжењери, архитекте и градитељи образовани у европским центрима, постављени на руководећим местима у Грађевинском одељењу Министарства унутраших дела ${ }^{11}$ и у окружним начелствима, попут Јана Неволеа, Јована Шлихте, Павла Ђоновића, Адолфа Јакша, Августа Ланга, Винцеца Кнеђерског, Августа Цимермана, Еразмуса Кломинског, Николе Јанковића и других (Класицизам 1966: 32-33). Тако је постепеном сменом градитељских струја заокружено, као специфично у развоју сакралне архитектуре Кнежевине Србије, време прве владавине кнеза Милоша Обреновића.

Даља истраживања сакралне архитектуре из времена прве владавине кнеза Милоша Обреновића и употпуњавање листе имена градитеља и њихових опуса, допринеће целовитијој слици о архитектури Србије XIX века. Многи од поменутих храмова су до данас више пута дограђивани и преобликовани, чиме је знатно измењен њихов изворни изглед. То у великој мери отежава право сагледавање како токова сакралне архитектуре настале у време између 1815. и 1839. године, тако и градитеља, као њених носилаца, у ширем контексту балканске сакралне архитектуре тог времена. Компаративне анализе са градитељским остварењима из истог периода у Грчкој, Бугарској, Македонији, Албанији, те истраживања појединачних градитељских тајфи на тим просторима, помогле би у прецизнијем идентификовању струја и центара из којих можда потичу неки од градитеља о којима је било речи, те бољем разумевању њихових узора и њиховог образовања.

\section{ИЗВОРИ}

AC (Архив Србије), КК (Кнежева кнацеларија) 1815-1839, кутије IX, XIX, XXI, XXVI

АС (Архив Србије), МБ (Митрополија београдска)

АС (Архив Србије), МПс (Министарство просвете)

\footnotetext{
${ }^{11}$ Које касније, 1862. године, прераста у Министарство грађевина. Вид.: Костић 2016: 25.
} 


\section{ЛИТЕРАТУРА}

БогдАновић, Марија, Сузана Новчић. „Храм Силаска Св. Духа у Краљеву (архитектура и иконостас)." У: ТАСић, Никола, Драган Драшковић, Љубодраг Ристић (ур.). Pуgo Поље, Карановаи, Кратево: (оg йрвих йомена gо Првої светискої райа). Научни скуп, БеоградКраљево, 14-16. август 1997. Београд: Балканолошки институт САНУ; Краљево: Народни музеј (Bogdanović, Marija, Suzana Novčić. „Hram Silaska Sv. Duha u Kraljevu (arhitektura i ikonostas)." U: TAsić, Nikola, Dragan Drašković, Ljubodrag Ristić (ur.). Rudo Polje, Karanovac, Kraljevo: (od prvih pomena do Prvog svetskog rata). Naučni skup, Beograd-Kraljevo, 14-16. avgust 1997. Beograd: Balkanološki institut SANU; Kraljevo: Narodni muzej), 2000, 295-313.

ВиЋентић, Тања. „Хаџи Никола Живковић у Србији кнеза Милоша Обреновића и кнеза Алек-

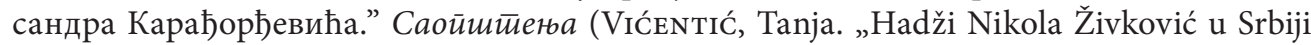
kneza Miloša Obrenovića i kneza Aleksandra Karađorđevića." Saopštenja) XLII (2010): 319-338.

Вујић, Јоаким. Пуйешейсвије ӣo Сербији. Књ. І. Београд: Српска књижевна задруга (Vuјс́́, Joakim. Putešetsvije po Serbiji. Knj. I. Beograd: Srpska književna zadruga), 1901.

Вујић, Јоаким. Пуйешетисвије йо Сербији. Књ. II. Београд: Српска књижевна задруга (Vuјс́́, Joakim. Putešetsvije po Serbiji. Knj. II. Beograd: Srpska književna zadruga), 1902.

Вујовић, Бранко. Црквени сйоменици на йоgручју іраga Беоїраga. = Les monuments religieux dans la region de la ville de Belgrade. Кю. 2, Шире йоgручје їраga. Београд: Завод за заштиту споменика културе града Београда (Vujović, Branko. Crkveni spomenici na području grada Beograda. = Les monuments religieux dans la region de la ville de Belgrade. Knj. 2, Šire područje grada. Beograd: Zavod za zaštitu spomenika kulture grada Beograda), 1973.

Вујовић, Бранко. Бранковина. Београд: Републички завод за заштиту споменика културе (VuJović, Branko. Brankovina. Beograd: Republički zavod za zaštitu spomenika kulture), 1983.

Вујовић, Бранко. Уметиносии обновльене Србије: 1791-1848. Београд: Просвета - Републички завод за заштиту споменика културе (Vujović, Branko. Umetnost obnovljene Srbije: 1791-1848. Beograd: Prosveta - Republički zavod za zaštitu spomenika kulture), 1986.

Вујовић, Бранко. Саборна ирква у Беоїраgу. Београд: Народна књига - Алфа (Vujović, Branko. Saborna crkva u Beogradu. Beograd: Narodna knjiga - Alfa), 1996.

Ђокић, Небојша, Љубодраг Поповић (ур.). Браничевска ейархија у йрвој йоловини ХІХ века. Пожаревац: Историјски архив (Đокіс́, Nebojša, Ljubodrag Popović (ur.). Braničevska eparhija u prvoj polovini XIX veka. Požarevac: Istorijski arhiv), 2005.

Ђокић, Небојша. „Храм Сошествија Светог Духа у Крагујевцу.” У: КРСтИћ, Зоран (ур.). Сйоменииа gва века Сӣаре иркве у Країујевиу (1818-2018). Крагујевац (Đокіс́, Nebojšа. „Hram Sošestvija Svetog Duha u Kragujevcu." U: KRstić, Zoran (ur.). Spomenica dva veka Stare crkve u Kragujevcu (1818-2018). Kragujevac), 2018, 93-127.

ЂорЂевит, Тихомир. Из Србије кнеза Милоша: Куличурне йрилике оg 1815 go 1839. Београд: Издавачка књижарница Геце Кона (ĐorĐević, Tihomir. Iz Srbije kneza Miloša: Kulturne prilike od 1815 do 1839. Beograd: Izdavačka knjižarnica Gece Kona), 1922.

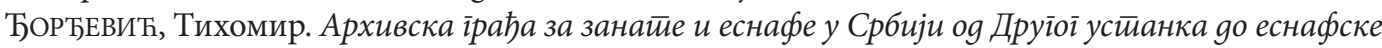
yреgбе 1847. Београд: Српска краљевска академија (ĐoRĐEvić, Tihomir. Arhivska građa za zanate i esnafe u Srbiji od Drugog ustanka do esnafske uredbe 1847. Beograd: Srpska kraljevska akademija), 1925. 


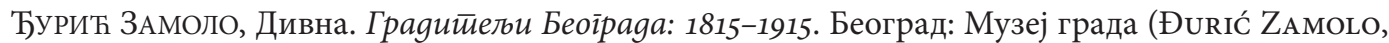
Divna. Graditelji Beograda: 1815-1915. Beograd: Muzej grada), 2011.

КАСАЛИЦА, Владислав. „Саборна црква у Пожаревцу.” У: Сйомениии Смеgеревль а и Браничева, 1. Смедерево: Регионални завод за заштиту споменика културе (KASALICA, Vladislav. „Saborna crkva u Požarevcu.” U: Spomenici Smederevlja i Braničeva, 1. Smederevo: Regionalni zavod za zaštitu spomenika kulture), 1997, 60-72.

КАшиЋ, Душан. „Рад кнеза Милоша на подизању и обнови цркава и манастира.” Гласник, службени листи Срйске йравославне иркве (KAšı́́, Dušan. „Rad kneza Miloša na podizanju i obnovi crkava i manastira." Glasnik, službeni list Srpske pravoslavne crkve) 10 (1960): 267-271.

Класииизам коg Срба: ірађевинарстиво. Књ. 2. Београд: Просвета (Klasicizam kod Srba: građevinarstvo. Knj. 2. Beograd: Prosveta), 1967.

КолАРИЋ, Миодраг. „Грађевине и грађевинари Србије од 1790. до 1839. године.” У: ПеРОвић, Душан (ур.). Зборник музеја Првоі̄ срӣскоі усйанка. I. Београд (Kolarić, Miodrag. „Građevine i građevinari Srbije od 1790. do 1839. godine.” U: Perović, Dušan (ur.). Zbornik muzeja Prvog srpskog ustanka. I. Beograd), 1959, 5-28.

Костић, Ана. Држава, ярушишво и ирквена уметиносй у Кнежевини Србији (1830-1882), докторска дисертација одбрањена 9. 12. 2016. Филозофски факултет, Универзитет у Београду (Kоsтіс́, Ana. State, Society and Religious art in the Principality of Serbia (1830-1882), Doctoral dissertation, 9. 12. 2016. Faculty of Philosophy, University of Belgrade), 2016.

Костић ЂЕкић, Ана. „Стара црква Светог архангела Михаила у Јагодини: њена архитектура и место у владарској идеологији Кнеза Милоша Обреновића.” У: ГАјИЋ, Александар (ур.). Симйосион Два века Сйаре иркве у Јайоgини. Научни скуп, Јагодина, 27-28. новембар 2016. Јагодина: Црквена општина при храму Светих архангела Михаила и Гаврила (КоSTIĆ ĐEкIĆ, Ana. „Stara crkva Svetog arhangela Mihaila u Jagodini: njena arhitektura i mesto u vladarskoj ideologiji Kneza Miloša Obrenovića." U: GAJIĆ, Aleksandar (ur.). Simposion Dva veka Stare crkve u Jagodini. Naučni skup, Jagodina, 27-28. novembar 2016. Jagodina: Crkvena opština pri hramu Svetih arhangela Mihaila i Gavrila), 2017, 33-54.

ЛАЗИЋ, Мирослав. „Ктитори и приложници у српској култури 19. и почетком 20. века.” У: МА-

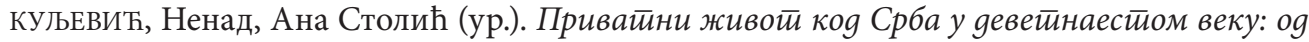

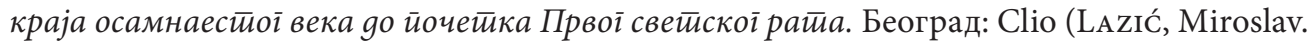
"Founders and contributors in Serbian culture of the $19^{\text {th }}$ and early $20^{\text {th }}$ century." In: MAKULJEvić, Nenad, Ana Stolić (eds.). Private Life among Serbs in the Nineteenth Century. Belgrade: Clio), 2006, 611-659.

ЛАзић, Мирослав. Црква Светиих Арханђела Михаила и Гаврила у Пожаревиу. Мастер рад одбрањен на Одељењу за историју уметности, Филозофског факултета, Универзитета у Београду (Lazıć, Miroslav. Crkva Svetih Arhanđela Mihaila i Gavrila u Požarevcu. Master rad odbranjen na Odeljenju za istoriju umetnosti, Filozofskog fakulteta, Univerziteta u Beogradu), 2008.

Љушић, Радош. Кнежевина Србија 1830-1839. Београд: Завод за уџбенике и наставна средства (Ljušıć, Radoš. Kneževina Srbija 1830-1839. Beograd: Zavod za udžbenike i nastavna sredstva), 2004.

МАКУљЕВИЋ, Ненад. „Црква у Карановцу - задужбина кнеза Милоша Обреновића: прилог проучавању односа владарске идеологије и црквене уметности.” У: ТАСИћ, Никола, Драган Драшковић, Љубодраг Ристић (ур.). Руgо Поље, Карановаи, Краљево: (og иррвих йомена

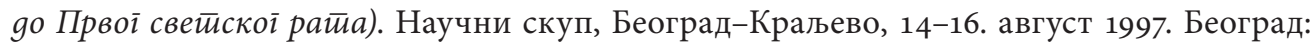


Балканолошки институт САНУ; Краљево: Народни музеј (MAKuLJEvić, Nenad. „Crkva u Karanovcu - zadužbina kneza Miloša Obrenovića: prilog proučavanju odnosa vladarske ideologije i crkvene umetnosti." U: TAsić, Nikola, Dragan Drašković, Ljubodrag Ristić (ur.). Rudo Polje, Karanovac, Kraljevo: (od prvih pomena do Prvog svetskog rata). Naučni skup, Beograd-Kraljevo, 14-16. avgust 1997. Beograd: Balkanološki institut SANU; Kraljevo: Narodni muzej), 2000, 283-294.

MAKULJEVIC, Nenad. “The zograph model of Orthodox painting in Southeast Europe 1830-1870." Balcanica XXXIV (2004): 385-405.

МАКУљЕВИЋ, Ненад. „Плурализам приватности: културни модели и приватни живот код Срба у ХІХ веку." У: МАКУљЕвић, Ненад, Ана Столић (ур.). Приватини живой коg Срба у

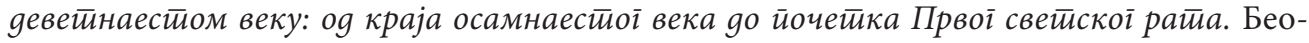
град: Clio (MakulJEvić, Nenad. „Pluralizam privatnosti: kulturni modeli i privatni život kod Srba u XIX veku." In: Makuljević, Nenad, Ana Stolić (eds.). Private Life among Serbs in the Nineteenth Century. Belgrade: Clio), 2006, 17-53.

МАкуљЕвић, Ненад (ур.). Саборни храм Светие Тројице у Врану: 1858-2008. Врање: Фонд „Свети Прохор Пчињски" Православне епархије врањске; Београд: Colorgrafx (MAKuljević, Nenad (ur.). Saborni hram Svete Trojice u Vranju: 1858-2008. Vranje: Fond „Sveti Prohor Pčinjski” Pravoslavne eparhije vranjske; Beograd: Colorgrafx), 2008.

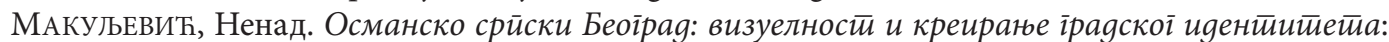
(1815-1878). Београд: Тору (MaкulJEvić, Nenad. Ottoman-Serbian Belgrade: Visuality and the Creation of Urban identity (1815-1878). Belgrade: Topy), 2014.

МАкУљевић, Ненад, Ана Костић, Ирена Ћировић. Храм Усйена Пресвейе Боі̄ороgице у Собини, 1820-2020. Врање: Православна епархија врањска - Свеправославно друштво „Преподобни Јустин Ћелијски и Врањски” (MAкULJEvić, Nenad, Ana Kostić, Irena Ćirović. Hram Uspenja Presvete Bogorodice u Sobini, 1820-2020. Vranje: Pravoslavna eparhija vranjska - Svepravoslavno društvo „Prepodobni Justin Ćelijski i Vranjski”), 2020.

МАневић, Зоран. Лексикон неимара. Београд: Грађевинска књига (Manević, Zoran. Leksikon neimara. Beograd: Građevinska knjiga), 2008.

МАРковић, Радослав. „Задужбине кнеза Милоша.” Просвеитни іласник (MARкоvić, Radoslav. „Zadužbine kneza Miloša.” Prosvetni glasnik) 3-5, LVIII (1942): 121-130.

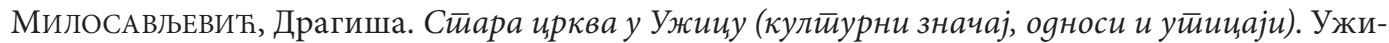
це: Спомен обележје „Кадињача” (Milosavljević, Dragiša. Stara crkva u Užicu (kulturni značaj, odnosi i uticaji). Užice: Spomen obeležje „Kadinjača”), 1991.

МилоСАвљЕвић, Драгиша. Осаћански неимари. Београд: Просвета; Прибој: Завичајни музеј (Milosavljević, Dragiša. Osaćanski neimari. Beograd: Prosveta; Priboj: Zavičajni muzej), 2000.

Митровић, Катарина. Тойчиgер: gвор кнеза Милоша Обреновића. Београд: Историјски музеј Србије (Mitrović, Katarina. Topčider: dvor kneza Miloša Obrenovića. Beograd: Istorijski muzej Srbije), 2008.

НЕСТОРОвИЋ, Богдан. „Преглед споменика Архитектуре у Србији XIX века.” Саойшиеююа Peйубличкоі завоgа за зашииитиу сйоменика кулӣуре (Nestorović, Bogdan. „Pregled spomenika Arhitekture u Srbiji XIX veka." Saopštenja Republičkog zavoda za zaštitu spomenika kulture) X (1974): 141-168.

Несторовит, Богдан. Архийекӣура Србије у XIX веку. Београд: Art press (Nestorović, Bogdan. Arhitektura Srbije u XIX veku. Beograd: Art press), 2006. 


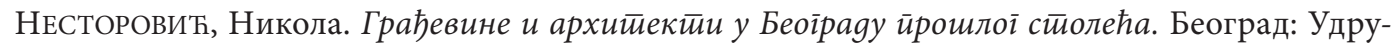
жење југосл. инжењера и архитекта (Nestorović, Nikola. Građevine i arhitekti u Beogradu prošlog stoleća. Beograd: Udruženje jugosl. inženjera i arhitekta), 1937.

ПАвЛОвић, Доброслав. „Конзерваторско-рестаураторски радови у Београду (Три зграде из времена кнеза Милоша).” Гоgишғьк Музеја їpaga Беоі̄paga (PAvlović, Dobroslav. „Konzervatorsko-restauratorski radovi u Beogradu (Tri zgrade iz vremena kneza Miloša).” Godišnjak Muzeja grada Beograda) II (1955): 271-306.

ПАвловић, Доброслав. Цркве брванаре у Србији. Београд: Републички завод за заштиту споменика културе (PAVlović, Dobroslav. Les Vielles eglises serbes construites en bois. Belgrade: Institut de la République pour la protection des monuments culturels), 1962.

ПАвЛОвИћ, Доброслав. „Цркве брвнаре - градитељство.” У: ПАвићЕвић ПоПОвић, Радмила, Доброслав Павловић, Радомир Станић. Молийва у іори. Цркве брвнаре у Србији. Београд: Републички завод за заштиту споменика културе (PAVlović, Dobroslav. „Crkve brvnare - graditeljstvo.” U: PavićEvić Popović Radmila, Dobroslav Pavlović, Radomir Stanić. Molitva u gori. Crkve brvnare u Srbiji. Beograd: Republički zavod za zaštitu spomenika kulture), 1994, 21-37.

ПетРОвић, Мита. Финансије и устианове обновљене Србије gо 1842. Књ. І. Београд: Државна штампарија Краљевине Србије (Ретrović, Mita. Finansije i ustanove obnovljene Srbije do 1842. Knj. I. Beograd: Državna štamparija Kraljevine Srbije), 1897.

ПЕтровиЋ, Мита. Финансије и устианове обновљене Србије gо 1842. Књ. ІІІ. Београд: Државна штампарија Краљевине Србије (Ретrović, Mita. Finansije i ustanove obnovljene Srbije do 1842. Knj. III. Beograd: Državna štamparija Kraljevine Srbije), 1899.

ПоПовски, Аритон. „Тајниот јазик на мајсторите градители од Река.” У: ПолЕнАКовИк, Харалампие (ур.). Биіорски научно-кулитурни собири 1974-1975. Скопје: Мисла (Ророvsкі, Ariton. „Tajniot jazik na majstorite graditeli od Reka.” U: PolenakoviḰ, Haralampie (ur.). Bigorski naučno-kulturni sobiri 1974-1975. Skopje: Misla), 1976, 198-208.

Пузовић, Предраг. „Однос кнеза Милоша према вери и цркви.” У: КРСтић, Зоран (ур.). Сйоменица gва века Сйаре иркве у Країујевиу (1818-2018). Крагујевац (Puzović, Predrag. „Odnos kneza Miloša prema veri i crkvi.” U: Krstić, Zoran (ur.). Spomenica dva veka Stare crkve u Kragujevcu (1818-2018). Kragujevac), 2018, 81-89.

Слијепчевић, Ђоко. Истиорија Срйске йравославне иркве. Кюиїа 2. Og йочейка ХІХ века gо

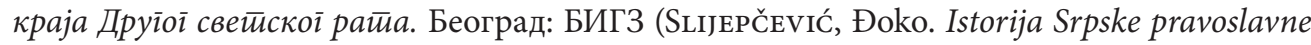
crkve. Knjiga 2. Od početka XIX veka do kraja Drugog svetskog rata. Beograd: BIGZ), 1991.

СРедојЕвИЋ, Александар. Герасим Ђорђевић, ейиской шабачки (1831-1839) и юеі̄ово gоба. Београд: Богословски факултет СПЦ (SRedojević, Aleksandar. Gerasim Đorđević, episkop šabački (1831-1839) i njegovo doba. Beograd: Bogoslovski fakultet SPC), 2004.

СтАнковић, Милош. „Архитектура Милошеве цркве у Крагујевцу.” У: КРСтит, Зоран (ур.). Сӣомении gва века Сйаре иркве у Країујевиу (1818-2018). Крагујевац (STAnкоvić, Miloš. „Arhitektura Miloševe crkve u Kragujevcu.” U: KRSTIĆ, Zoran (ur.). Spomenica dva veka Stare crkve u Kragujevcu (1818-2018). Kragujevac), 2018, 129-143.

СтАНОјЕвИЋ, Владимир. „Најстарије болнице у Београду.” Гоguшъак ірpaga Беоїраga (StAnojević, Vladimir. „Najstarije bolnice u Beogradu.” Godišnjak grada Beograda) VII (1960): 175-195.

СТРАњАКОвИЋ, Добривоје. „Кнез Милош према вери и цркви.” Гласник, службени листи Срйске йравославне иркве (Stranjaкović, Dobrivoje. „Knez Miloš prema veri i crkvi.” Glasnik, službeni list Srpske pravoslavne crkve) 10 (1960): 262-267. 
ЋиРовИЋ, Ирена. „Црква Свете Тројице у Трњану.” У: МАкуљЕвИЋ, Ненад (ур.). Сакрална $\bar{ш} о-$ йоірафија Неі̄оиинске Крајине. Неготин: Музеј Крајине (Ćırović, Irena. „Crkva Svete Trojice u Trnjanu.” U: Makuljević, Nenad (ur.). Sakralna topografija Negotinske Krajine. Negotin: Muzej Krajine), 2012, 261-270.

ФЕлдић, Драган. Сйари Пожареваи - зgана, неимари, жительи. Пожаревац: Компромис СЛ (Feldić, Dragan. Stari Požarevac - zdanja, neimari, žitelji. Požarevac: Kompromis SL), 1992.

ЏАмБАЗОвскИ, Климент. Грађа за истиорију макеgонской нароgа из архива Србије = Граѓa за истиоријатиа на макеgонскиоти нароg: оg архивоти на Србија. Т. 3. Кю. 2, (1874-1878). Београд: Архив Србије; Скопје: Архив на Македонија (DžАмвAzovsкi, Kliment. Građa za istoriju makedonskog naroda iz arhiva Srbije = Graźa za istorijata na makedonskiot narod: od arhivot na Srbija. T. 3. Knj. 2, (1874-1878). Beograd: Arhiv Srbije; Skopje: Arhiv na Makedonija), 1984.

ЏЕЛЕБИЋ, Милорад. Архивска іррађа за истиорију Народної музеја, књиїа ӣрва: Кнез Милоши и

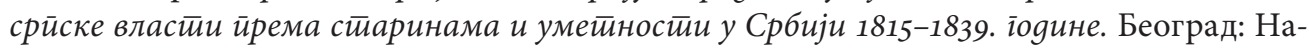
родни музеј (Džеlebić, Milorad. Arhivska građa za istoriju Narodnog muzeja, knjiga prva: Knez Miloš i srpske vlasti prema starinama i umetnosti u Srbiji 1815-1839. godine. Beograd: Narodni muzej), 1969.

\section{Ana D. Kostić \\ SACRAL ARCHITECTURE AND CHURCH BUILDERS IN THE PRINCIPALITY OF SERBIA DURING THE FIRST RULE OF PRINCE MILOŠ OBRENOVIĆ (1815-1839)}

Summary

In the period of the first rule of Prince Miloš Obrenović (1815-1839), many churches were erected and renovated in the Principality of Serbia. These activities included the personal political moves of the Prince toward forming the state. Thus, making a network of parishes and finding the builders had been of the utmost importance. During this politically, economically, and culturally dynamic period of the first rule of Prince Miloš Obrenović, the conditions affecting the development of the sacral building had been changing. As a result, in a relatively short time (three decades), hundreds of churches different in their typology had been built and renovated - starting from the wooden churches, single-nave churches without a bell tower, to those containing bell towers. The rising need to have more churches was met by hiring the builders from the Ottoman Empire, the southern Balkans - Ohrid, Bitolje, Veles, Vraneš, Kruševo, Carigrad (Constantinople), but also from Bosnia, mainly from Osat. Among these builders, the most renowned were Kosta Dimović, Andrija Sotirović, Janja Mihajlović, Nikola Đorđević, Hadži Nikola Živković, Dimitrije Sotirović, Nastas Stefanović, Sima Vironja, Miroslav Buljugija, Novak, Milutin Gođevac and his sons Aleksa, Đura, and Petar. This southern Balkans' building impact was dominant until the period 1837-1840 when the Cathedral Church in Belgrade was built by the educated builders from the Habsburg Empire, Friedrich Adam Querfeld and Franz Dobi. After building the Cathedral Church in Belgrade, 
upon the change in the government in 1842, but also the change in the cultural policy and church reformation, the dominant were the architects and the engineers educated in Europe. They were trusted with making plans, supervising, and building the churches in the Principality of Serbia. This shift represents the end of a dynamic and in many ways unique period in the sacral architecture of the Principality of Serbia.

Keywords: Principality of Serbia, first rule of Prince Miloš Obrenović, sacral architecture, builders from the Balkans. 